Case Report

\title{
Limbic Encephalitis with HU-Antibodies in T-cell Anaplastic Lymphoma. A Case Report
}

\author{
Carmela Gurrieri ${ }^{1}$, Andrea Visentin ${ }^{1}\left(\mathbb{C}\right.$, Cinzia Bussè ${ }^{2}$, Francesco Piazza ${ }^{1}$, Renzo Manara ${ }^{3}$, Livio Trentin ${ }^{1}(\mathbb{C}$ \\ and Chiara Briani ${ }^{2, *(D)}$
}

1 Hematology and Clinical Immunology Unit, Department of Medicine, University of Padua, 35128 Padua, Italy; carmela.gurrieri@unipd.it (C.G.); andrea.visentin@aopd.veneto.it (A.V.); francesco.piazza@unipd.it (F.P.); livio.trentin@unipd.it (L.T.)

2 Neurology Unit, Department of Neuroscience, University of Padua, 35128 Padua, Italy; cinzia.busse@aopd.veneto.it

3 Neuroradiology Unit, Department of Neuroscience, University of Padua, 35128 Padua, Italy; renzo.manara@unipd.it

* Correspondence: chiara.briani@unipd.it; Tel.: +39-049-8213600; Fax: +39-049-8751770

check for updates

Citation: Gurrieri, C.; Visentin, A.; Bussè, C.; Piazza, F.; Manara, R.; Trentin, L.; Briani, C. Limbic Encephalitis with HU-Antibodies in T-cell Anaplastic Lymphoma. A Case Report. Appl. Sci. 2021, 11, 6548. https://doi.org/10.3390/app11146548

Academic Editor: Laura Porretti

Received: 10 June 2021

Accepted: 12 July 2021

Published: 16 July 2021

Publisher's Note: MDPI stays neutral with regard to jurisdictional claims in published maps and institutional affiliations.

Copyright: (c) 2021 by the authors. Licensee MDPI, Basel, Switzerland. This article is an open access article distributed under the terms and conditions of the Creative Commons Attribution (CC BY) license (https:// creativecommons.org/licenses/by/ $4.0 /)$.
Featured Application: Anti-HU limbic encephalitis in lymphoma.

\begin{abstract}
Limbic encephalitis is a rare paraneoplastic neurological syndrome usually associated with small cell lung cancers, testicular and breast cancers or B-cell lymphomas. We herein report the first patients with paraneoplastic limbic encephalitis associated with HU antibodies and anaplastic T-cell lymphoma.
\end{abstract}

Keywords: T cell lymphoma; limbic encephalitis; paraneoplastic; HU antibodies

\section{Introduction}

Paraneoplastic neurological syndromes (PNS) are rare neurological disorders occurring in less than $1 \%$ of people, with malignancy not due to direct tumor infiltration or metastases, infection, ischemia, metabolic or nutritional deficits, nor chemotherapy side effects [1,2]. Hematological malignancies are rarely associated with PNS [3,4]. In the largest cohort of PNS patients (974 subjects) so far described, only 24 (2.7\%) had Hodgkin's lymphoma (HL) and 29 (3.2\%) non-Hodgkin lymphoma (NHL), all of cell type B [3]. The most common PNS was paraneoplastic cerebellar degeneration, often associated with anti-Tr antibodies. Limbic encephalitis has also been described in lymphomas, with antibodies to Tr and Ma2 [3]. Subsequently, the metabotropic glutamate receptor 5 (mGluR5) has been identified as another target antigen in limbic encephalitis in HL, also known as Ophelia syndrome. We report on the first patient with limbic encephalitis and HU antibodies, also known as Anti-ANNA1-associated encephalitis, in a T-cell anaplastic lymphoma [5].

\section{Case Report}

A 56-year-old man with an unremarkable past medical history started complaining of back pain, sexual and sphincteric disturbances (causa equine syndrome) and lower limb paralysis secondary to a paravertebral mass that a biopsy revealed to be an ALK (anaplastic lymphoma kinase) negative anaplastic T-cell lymphoma. Seizures were also present. Bone marrow biopsy was negative for disease localization. Cerebrospinal fluid analysis revealed central nervous system (CNS) involvement: pleocytosis, 260 white blood cells / $\mu \mathrm{L}$ (nv 0-5), comprising predominantly malignant $\mathrm{T}$ lymphocytes, proteins $4.77 \mathrm{~g} / \mathrm{L}$ (nv 0.15-0.45) and lactate $6.6 \mathrm{mmol} / \mathrm{L}$ (nv 1.1-2.4). Extensive microbiological testing for infectious agents was negative. Brain magnetic resonance imaging (MRI) showed hyperintense focal cerebral altered signal intensity with vasogenic edema and diffusion restriction involving the limbic 
system (right mesial temporal lobe, insula, cingulate gyrus and hypothalamus). Laboratory findings were unremarkable, except for an LDH increase $(540 \mathrm{U} / \mathrm{L}, \mathrm{n} . \mathrm{v} .<200 \mathrm{U} / \mathrm{L})$. A panhypopituitarism with diabetes insipidus likely secondary to lymphoma infiltration was also diagnosed and managed successfully with desmopressin, levothyroxine, cortisone acetate and sodium replacement therapy. Taking into account CNS involvement, the patient was treated with three courses of MATRIX (methotrexate, cytarabine and thiotepa), followed by two courses of ICE (ifosfamide, carboplatin and etoposide), with resolution of neurologic symptoms, radiologic findings and lymphoma remission [6]. Soon after the second course of ICE, the patient developed confusion, memory loss, and religious delirium. Generalized seizures also recurred. A neuropsychological evaluation demonstrated a significant impairment restricted to the memory domain, whereas executive and visuospatial functions were partially involved (Mini-Mental State Exam = 26/30). Brain and spine MRI, as well as whole body positron emission tomography (PET)-MRI, while ruling out lymphoma progression, revealed recurrence of focal cerebral altered signal intensity with diffusion restriction involving the limbic system (Figure 1A). Autoantibody screening was positive for the anti-HU (antineuronal nuclear autoantibody type 1) antibody. Based on the combination of symptoms, MRI findings and paraneoplastic antibodies, a diagnosis of anti-HU limbic encephalitis was made (Table 1). A further neuropsychological evaluation revealed a more extensive impairment in anterograde amnesia, fluencies, processing speed and executive and visuo-spatial domain. After treatment with methylprednisolone ( $1 \mathrm{~g}$ IV for three days) and seven sessions of plasma exchange, the patient regained his status ante (Figure 1B). He then started steroid maintenance therapy and underwent autologous stem cell transplantation with thiotepa/carmustine as a conditioning regimen. The response to therapy, assessed by PET-MRI and brain and spine MRI, showed a complete remission of lymphoma and substantial improvement of the encephalitis MRI findings, with only few small spots of cerebral altered signal intensity with vasogenic edema being left. Brain MRI control two months later confirmed the same findings, but also revealed hippocampal atrophy as a long-term impact of limbic encephalitis (Figure 1C). The patient therefore started regular hematological follow-up. He died one year later, still in hematological remission, as a consequence of pneumonia.

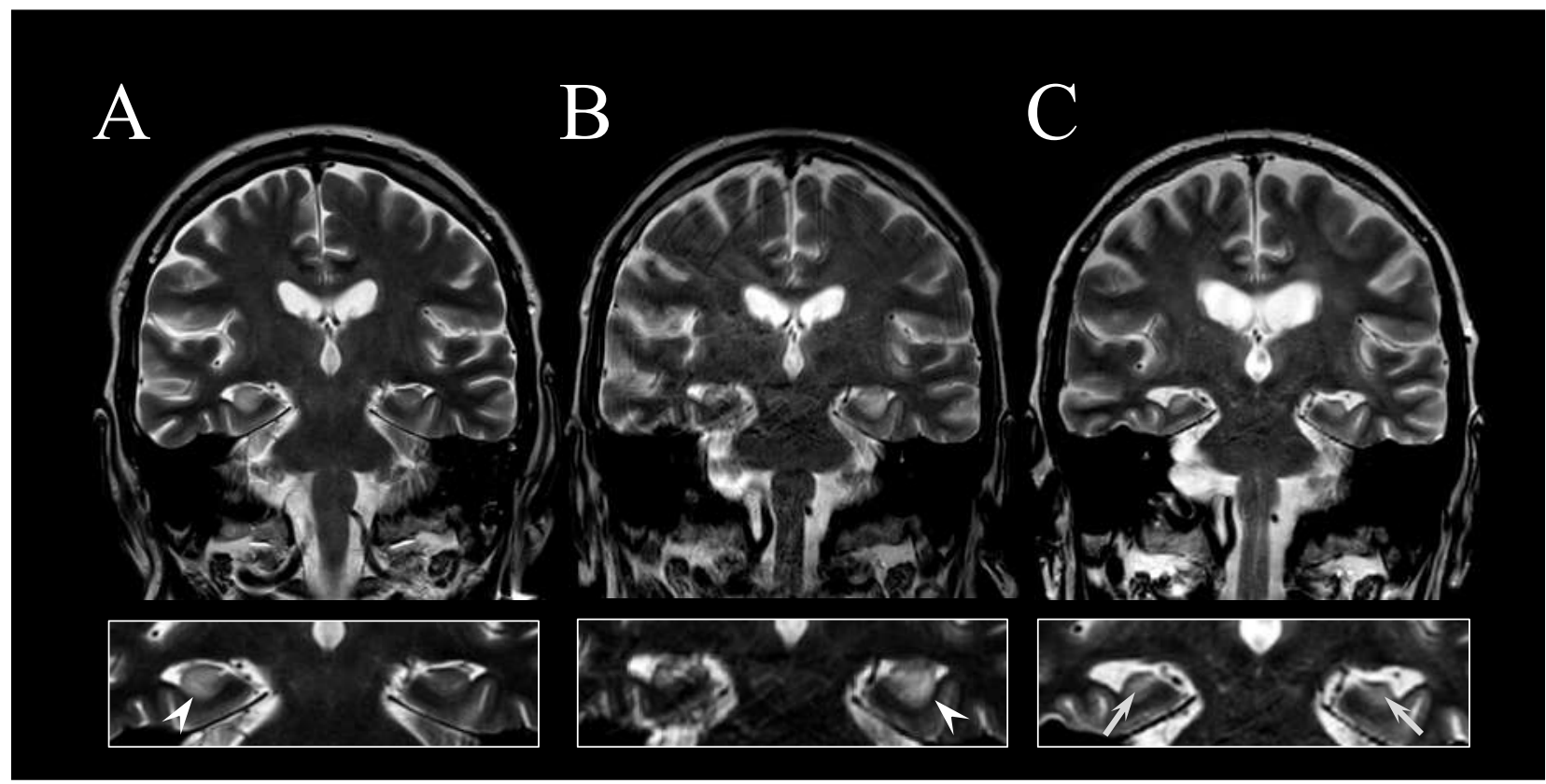

Figure 1. Encephalic MRI at encephalitis onset and during the follow-up. Coronal T2 images at the level of the hippocampal formations at onset (A) +4 and (B) $+9,(\mathbf{C})$ months later showing edema of the hippocampal formation (arrowhead) resulting in bilateral atrophy (arrows). 
Table 1. Biochemical data.

\begin{tabular}{|c|c|c|c|c|c|}
\hline Markers & Normal Value & Patient's Data & Markers & Normal Value & Patient's Data \\
\hline \multicolumn{6}{|c|}{ Blood analysis } \\
\hline WBC & $4.0-11 \times 10^{9} / \mathrm{L}$ & $3.5 \times 10^{9} / \mathrm{L}$ & LDH & $135-225 \mathrm{U} / \mathrm{L}$ & $173 \mathrm{U} / \mathrm{L}$ \\
\hline Lymphocyte & $1.1-4.8 \times 10^{9} / \mathrm{L}$ & $0.7 \times 10^{9} / \mathrm{L}$ & Creatinine & 59-100 $\mu \mathrm{mol} / \mathrm{L}$ & $43 \mathrm{~mol} / \mathrm{L}$ \\
\hline Neutrophils & $1.8-7.8 \times 10^{9} / \mathrm{L}$ & $2.1 \times 10^{9} / \mathrm{L}$ & AST & $10-45 \mathrm{U} / \mathrm{L}$ & $17 \mathrm{U} / \mathrm{L}$ \\
\hline Hemoglobin & $140-170 \mathrm{~g} / \mathrm{L}$ & $87 \mathrm{~g} / \mathrm{L}$ & ALT & $10-50 \mathrm{U} / \mathrm{L}$ & $32 \mathrm{U} / \mathrm{L}$ \\
\hline Platelets & $150-450 \times 10^{9} / \mathrm{L}$ & $157 \times 10^{9} / \mathrm{L}$ & Protein & $64-83 \mathrm{~g} / \mathrm{L}$ & $48 \mathrm{~g} / \mathrm{L}$ \\
\hline ESR & $2-37 \mathrm{~mm} / \mathrm{h}$ & $5 \mathrm{~mm} / \mathrm{h}$ & IgG & $7-16 \mathrm{~g} / \mathrm{L}$ & $6.05 \mathrm{~g} / \mathrm{L}$ \\
\hline CRP & $<6 \mathrm{mg} / \mathrm{L}$ & $7 \mathrm{mg} / \mathrm{L}$ & Presepsin & $57-37 \mathrm{~g} / \mathrm{L}$ & $148 \mathrm{ng} / \mathrm{L}$ \\
\hline \multicolumn{6}{|c|}{ Cerebrospinal fluid tests } \\
\hline Protein & $0.15-0.45$ & $0.6 \mathrm{~g} / \mathrm{L}$ & Glucose & $2.2-3.9 \mathrm{mmol} / \mathrm{L}$ & $2.7 \mathrm{mmol} / \mathrm{L}$ \\
\hline Lactate & $1.1-2.4 \mathrm{mmol} / \mathrm{L}$ & $3.9 \mathrm{mmol} / \mathrm{L}$ & Red cells & $0 / \mu \mathrm{L}$ & $0 / \mu \mathrm{L}$ \\
\hline anti-HU & negative & positive & CASPR2 & negative & negative \\
\hline anti-AMPA & negative & negative & anti-LG1 & negative & negative \\
\hline anti-GABA & negative & negative & anti-YO & negative & negative \\
\hline anti-NMDAR & negative & negative & anti-RI & negative & negative \\
\hline anti-amphiphysin & negative & negative & oligoclonal bands & negative & negative \\
\hline
\end{tabular}

$\mathrm{WBC}=$ white blood cells, $\mathrm{ESR}=$ erythrocytes sedimentation rate, $\mathrm{CRP}=\mathrm{C}$-reactive protein $\mathrm{LDH}=$ lactic dehydrogenase, $\mathrm{AST}=$ aspartic aminotransferase, $\mathrm{ALT}=$ alanine aminotransferase.

\section{Discussion}

PNS are rarely associated with B-cell lymphomas, with paraneoplastic cerebellar degeneration being the most common neurological manifestation. To the best of our knowledge, this is the first reported patient with limbic encephalitis associated with the HU antibody, also known as Anti-ANNA1-associated encephalitis, in a T-cell lymphoma [3]. The paraneoplastic syndrome responded well to immunomodulant therapy and lymphoma treatment, with the patient regaining both full functionality and lymphoma remission.

Metabotropic antigens, namely mGluR5, have recently been identified as possible antibody targets in limbic encephalitis in lymphomas. Limbic encephalitis with antimGluR5 antibodies shows a good prognosis, as was the case in our patient and in the first described subject with Ophelia syndrome [5]. The possibility of a concurrent small cell lung cancer (known to express the HU antigen) has likely been ruled out considering the negative whole-body PET-MRI during the active encephalitis phase [7]. Another two patients with $\mathrm{HU}$-associated limbic encephalitis and HL had previously been described in one case with clinical response to therapy $[8,9]$.

The pathogenesis of PNS in hematological malignancies is, however, still unclear, being onconeural antigens not expressed by lymphoma cells. The favorable outcome of the PNS is likely due to the limited central nervous system damage, once/whenever the syndrome is recognized, and appropriate treatment is started in the early phases of the disease [10].

In conclusion, we report on a rare case of paraneoplastic limbic encephalitis associated with HU antibodies in a patient with anaplastic T-cell lymphoma that completely responded to the hematological therapy. MATRIX and ICE therapy completely eradicated the CNS localization of the lymphoma, as supported by negative CSF and neuroimaging. However, a paraneoplastic syndrome occurred, as supported by onconeural antibody positivity and brain neuroimaging as well as the response to therapy.

Author Contributions: C.G., A.V., F.P., L.T. evaluated the patient and managed hematological malignancies, R.M. performed radiological exams, C.B. (Cinzia Bussè) and C.B. (Chiara Briani) managed neurological complications and performed neuropsychological tests, respectively. All authors have read and agreed to the published version of the manuscript.

Funding: This research received no external funding. 
Institutional Review Board Statement: The study was conducted according to the guidelines of the Declaration of Helsinki. Ethical review and patient consent were waived for this study since the patients had already died.

Informed Consent Statement: The study was conducted according to the guidelines of the Declaration of Helsinki. Ethical review and patient consent were waived for this study since the patients had already died.

Data Availability Statement: Data will be shared after private contact of the corresponding author.

Acknowledgments: We would like to thank our nurses for their pivotal role in the management of this patient, AIRC to LT and Ricerca per Credere nella Vita RCV odv that supports the Hematology Unit.

Conflicts of Interest: Authors have no conflict of interest.

\section{References}

1. Darnell, R.B.; Posner, J.B. Paraneoplastic syndromes involving the nervous system. N. Engl. J. Med. 2003, 349, 1543-1554. [CrossRef] [PubMed]

2. Graus, F.; Delattre, J.Y.; Antoine, J.E.; Dalmau, J.; Giometto, B.; Grisold, W.; Honnorat, J.; Smitt, P.S.; Vedeler, C.; Verschuuren, J.J.G.M.; et al. Recommended diagnostic criteria for paraneoplastic neurological syndromes. J. Neurol. Neurosurg. Psychiatry 2004, 75, 1135-1140. [CrossRef] [PubMed]

3. Briani, C.; Vitaliani, R.; Grisold, W.; Honnorat, J.; Graus, F.; Antoine, J.C.; Bertolini, G.; Giometto, B. PNS Euronetwork. Spectrum of paraneoplastic disease associated with lymphoma. Neurology 2011, 76, 705-710. [CrossRef] [PubMed]

4. Briani, C.; Visentin, A.; Campagnolo, M.; Salvalaggio, A.; Ferrari, S.; Cavallaro, T.; Manara, R.; Gasparotti, R.; Piazza, F. Peripheral nervous system involvement in lymphomas. J. Peripher. Nerv. Syst. 2019, 24, 5-18. [CrossRef] [PubMed]

5. Lancaster, E.; Martinez-Hernandez, E.; Titulaer, M.J.; Boulos, M.; Weaver, S.; Antoine, J.C.; Liebers, E.; Kornblum, C.; Bien, C.G.; Honnorat, J.; et al. Antibodies to metabotropic glutamate receptor 5 in the Ophelia syndrome. Neurology 2011, 77, 1698-1701. [CrossRef] [PubMed]

6. $\quad$ Ferreri, A.J.M.; Doorduijn, J.K.; Re, A.; Cabras, M.G.; Smith, J.; Ilariucci, F.; Luppi, M.; Calimeri, T.; Cattaneo, C.; Khwaja, J.; et al. International Extranodal Lymphoma Study Group (IELSG). MATRix-RICE therapy and autologous haematopoietic stem-cell transplantation in diffuse large B-cell lymphoma with secondary CNS involvement (MARIETTA): An international, single-arm, phase 2 trial. Lancet Haematol. 2021, 8, e110-e121. [CrossRef]

7. Carr, I. The Ophelia syndrome: Memory loss in Hodgkin's disease. Lancet 1982, 319, 844-845. [CrossRef]

8. Hentschke, S.; Malzfeldt, E.; Salwender, H.J.; Braumann, D.; Stang Aand Hentschke, M. Hu-antibody positive limbic encephalitis in a patient with Hodgkin lymphoma. Leuk. Lymphoma. 2008, 49, 2374-2376. [CrossRef] [PubMed]

9. Laffon, M.; Giordana, C.; Almairac, F.; Benchetrit, M.; Thomas, P. Anti-Hu-associated paraneoplastic limbic encephalitis in Hodgkin lymphoma. Leuk. Lymphoma. 2012, 53, 1433-1434. [CrossRef] [PubMed]

10. Graus, F.; Ariño, H.; Dalmau, J. Paraneoplastic neurological syndromes in Hodgkin and non-Hodgkin lymphomas. Blood 2014, 123, 3230-3238. [CrossRef] [PubMed] 